\section{REFERENCES}

1.Arutyunov, Yu. S., Borisova, N.V. andKolesnichenko, S. G. (1983). O klassifikatsii metodov aktivnogo obucheniya [On the classification of active learning methods]. Interagency school-seminar on active teaching methods "Application of active teaching methods in the learning process", Riga, pp. 21 - 24. [in Russian].

2. Verbitskiy, A. A. (1991). Aktivnoe obuchenie v vyisshey shkole: kontekstnyiy podhod [Active learning in higher education: contextual approach]. Moscov, Vyisshaya shkola, 208 p. [in Russian].

3. Dyachenko-Bogun, M. (2014). Aktyvni metody navchannya $\mathrm{u}$ vyshhomu navchalnomu zakladi [Active teaching methods at a higher educational institution]. Origins of pedagogical skill, vol. 14, pp. $74-79$. [in Ukrainian].

4. Ocheretna, N. D. (2013). Osoblyvosti zastosuvannya dilovyx igor $u$ procesi vyvchennya inozemnoyi movy u vyshhyx navchalnyx zakladax [Features of the use of business games in the process of learning a foreign language in higher education]. Pedagogical Education: Theory and Practice, vol. 14, pp. 206 - 210. [in Ukrainian].

5. Pasichnyk, O.O. (2014). Osoblyvosti vykorystannya dilovyx igor na zanyattyax z inozemnoyi movy u VNZ [Features of the use of business games in foreign language classes at universities]. Scientific herald of Uzhhorod University: Series: Pedagogy. Social work, Uzhgorod, Goverla, vol. 30, pp. 125-127. [in Ukrainian].

6. Xomenko, O. O. (1994). Navchalni dilovi igry yak zasib formuvannya profesijnyx umin studentiv texnikumiv i koledzhiv (na prykladi budivelnyx specialnostej) [Educational business games as a means of forming professional skills of students of technical schools and colleges (for example, construction specialties)]. Extended abstract of candidate's thesis. Kyiv, 34 p. [in Ukrainian].

Стаття надійшла до редакції 18.10.2018

УДК 371.13:796

DOI:

Олександр Солтик, кандидат наук з фізичного виховання $і$ спорту, доцент, завідувач кафедри теорії $і$ методики фізичного виховання $і$ спорту Хмельницького національного університету

\title{
ФОРМУВАННЯ ПРОФЕСІЙНОЇ НАДІЙНОСТІ МАЙБУТНЬОГО ВЧИТЕЛЯ ФІЗИЧНОї КУЛЬТУРИ
}

У статті розглядається проблема формування професійної надійності майбутніх вчителів фізичноі культури. Окрема увага приділена дослідженню стану сформованості професійной надійності майбутніх діючих вчителів фізичної культури. Дослідження діючих вчителів дозволило побудувати модельні характеристики, встановити критерії і шкалу оиінювання показників професійної надійності. Важливим механізмом покращення формування професійної надійності майбутнього вчителя фізичної культури виступає реалізація педагогічних умов в освітньому процесі, функціонування педагогічної системи формування надійності, застосування окремих методів і методик формування надійністних характеристик.

Ключові слова: професійна надійність; майбутній вчитель; формування професійної надійності, вчитель фізичної культури.

Jim. 6.

Oleksandr Soltyk, Ph.D. (Physical Education and Sport), Associate Professor, Head of the Theory and Methods of Physical Education and Sport Department Khmelnytskiy National University

\section{FORMATION OF PROFESSIONAL RELIABILITY OF FUTURE TEACHERS OF PHYSICALEDUCATION}

The article deals with the formation of professional reliability of future teachers of physical education. Elaboration of personal notion, determination of the content and a structure of the analyzed issue served as a premise for analysis of professional reliability of future teachers.

Special attention is paid to analysis of the level of formation of professional reliability of future and active teachers of physical education. An analysis of active teachers allowed constructing model characteristics, define criteria and scale of assessment of indices of professional reliability. Significant discrepancies by all indices that characterize reliability of future and active teachers have been revealed with experimental means.

Revealing lagging aspects of professional reliability of future teachers of physical education allows defining the priority areas with the purpose of their improvement within professional training.

An important mechanism of improvement of formation of professional reliability of future teachers of physical education is realization of pedagogical conditions within educational process, functioning of pedagogical system of reliability formation, application of individual means and methods of formation of personal characteristics. 
Efficacy of the proposed means aimed at formation of professional reliability of future teachers of physical education has been proven by the results of pedagogical experiment, in which values of the indices of professional reliability were significantly improved with representatives of experimental group. Significant improvement within the experimental group was achieved via index of deviation from the lesson plan, which characterizes faultlessness of professional reliability. Also, significant improvements have been registered by the index of motor density of a lesson, which characterizes efficiency of professional activity of future teachers of physical education.

Keywords: professional reliability; a future teacher; formation of professional reliability; a teacher of physical education.

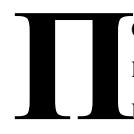

остановка проблеми у загальному вигляді та її зв'язок із важливими науковими завданнями. Ефективність здійснення будь-якої професійної діяльності, в тому числі і в педагогічній сфері, в значній мірі обумовлено рівнем професійноїпідготовки фахівця. Сучасні зміни, які відбуваються у вищій школі, реформування освітянської галузі, впровадження в освітній процес нових, інноваційних підходів і методів навчання тощо потребують своєчасного реагування та внесення в процес професійної підготовки необхідних змін, здійснення корекції навчальних планів, перегляд професійно-важливих фахових компетентностей тощо.

Звертаючи увагу на професійну діяльність вчителя фізичної культури відмічаємо ще більший інтерес з боку науковців до цієї професії, викликаний збільшенням іiі ролі і значення в сучасних умовах. Постать вчителя фізичної культури повноправно можемо розглядати, як головного суб'єкта у школі, зусилля якого спрямовані на протидію зниженню рухової активності молоді, боротьбу з малорухомим способом життя, пропагандою здорового способу життя. Зважаючи на це важливим науковим завданням вищої школи $€$ пошук нових напрямів і вдосконалення існуючої системи професійної підготовки майбутніх вчителів фізичної культури. Серед нових прогресивних напрямів покращення професійної підготовки педагогів розглядаємо формування професійної надійності майбутніх вчителів фізичної культури. Перенесення надійністних характеристик в освітній процес, формування надійного педагога розглядаємо, як одне із важливих завдань вищої школи.

Аналіз основних досліджень і публікацій. Не зважаючи на значний науковий інтерес, проблема формування професійної надійності педагогів, зокрема вчителів фізичної культури, не знайшла повноцінного відображення у наукових дослідженнях. Більшість вчених розглядаючи професійну надійність пов'язують її з якостями фахівця.

О. Осадчук під професійною надійністю педагога розуміє інтегративну властивість, що відображає єдність особистісних, суб'єктних і індивідних властивостей, які забезпечують збереження якості реалізації педагогічних функцій у змінних умовах за допомогою механізму саморегуляції $[1,26]$.

Д. Романов [2] пов'язує професійну надійність педагога із стійкістю, резистентністю до емоційного вигорання та інших негативних чинників, які впливають на професійну діяльність

Інші науковці [5; 6] при досліджені надійності педагога акцентують увагу здебільш на його оцінювальній діяльності. Відповідно надійність вчителя характеризується тим, як точно і правильно була виставлена оцінка вчителем. Так, Sandra Johnson [6] відмічає те, що на точність оцінювання успішності учнів впливає багато чинників, серед яких стать, соціально-економічний стан, зусилля і поведінка. Важливість надійності оцінювання у діяльності вчителя наголошують Catharine Parkes, Sarah Maughan [5]. Автори пов'язують надійність із зміцненням довіри до оцінки вчителя, забезпеченням якості вчительських рішень, розробкою ефективних моделей оцінювання на різних етапах освіти.

Серед важливих характеристик, які лежать в основі надійності В. Небиліцин, виділив працездатність фахівця, його здібність зберігати робочі параметри протягом заданого періоду, при різних ускладнюючих обставинах. Відповідно одним із напрямів формування професійної надійності фахівця є підвищення працездатності.

Незважаючи на різні погляди щодо формування професійної надійності важливим $є$ врахування специфіки і особливостей професії. Виходячи із цього метою нашого дослідження стало формування дієвої системи формування професійної надійності майбутнього вчителя фізичної культури.

Виклад основного матеріалу дослідження. Першочерговим завданням на шляху вирішення головної проблеми формування професійної надійності майбутнього вчителя фізичної культури стало формулювання робочого поняття та наповнення його змістом. Всебічний аналіз існуючих визначень та термінів, пов'язаних із надійністю в різних сферах життєдіяльності людини, та врахування специфіки професійної діяльності вчителя фізичної культури, дозволило нам сформулювати головне поняття професійної надійності. Так, під професійною надійністю ми розуміємо професійну активність педагога, що 
характеризується безпомилковістю, ефективністю та самовіддачею, під впливом змінних умов професійно-педагогічного середовища упродовж уроку з фізичної культури [3].

Згідно із нашим задумом вихідними даними, що характеризують професійну надійність майбутнього вчителя фізичної культури, виступають безпомилковість, ефективність та самовіддача. В свою чергу, безпомилковість визначається двома показниками: змістовим наповнення уроку та відхиленням уроку від плануконспекту; ефективність професійної діяльності встановлюємо за показниками моторної і загальної щільності уроку; самовіддача педагога розкривається за показниками вербальної (мовленнєвої) та функціональної складових.

Разом із тим для ефективного формування професійної надійності майбутнього вчителя фізичної культури обов'язковим етапом є розробка дієвого механізму здійснення впливів у процесі професійної підготовки майбутнього фахівця. Концептуальну основу формування професійної надійності майбутнього вчителя склала, розроблена нами педагогічна система, яка складається із шести підсистем: концептуальноцільової, теоретико-методологічної, проектувальноопераційної, освітньо-формувальної, діяльнісноадаптивної, контрольно-оцінювальної [4]. Важливою обставиною формування професійної надійності є реалізація в ході освітнього процесу сукупності педагогічних умов. До складу таких педагогічних умов нами було віднесено: міждисциплінарнуінтеграцію узмісті професійної підготовки майбутніх вчителів фізичної культури; врахування індивідуально-психологічних особливостей студентів у формуванні професійної надійності; вплив зовнішніх умов професійнопедагогічного середовища на формування професійної надійності майбутніх вчителів фізичної культури; удосконалення фізичної підготовки майбутніх вчителів фізичної культури на основі диверсифікації та збільшення арсеналу фізичних вправ; використання інноваційних форм, методів і технологій навчання для формування професійної надійності майбутніх вчителів фізичної культури; орієнтацію практичної підготовки студентів на формування професійної надійності; суб'єкт-суб' єктну взаємодію науковопедагогічних працівників спрямовану на формування професійної надійності майбутніх вчителів.

Окрім формулювання поняття, розробки педагогічної системи, необхідним кроком на шляху формування професійної надійності $€$ впровадження в освітній процес сукупності методів і методик, здійснення відповідних впливів. Підгрунтям для реалізації педагогічної системи в освітньому процесі стало дослідження реального стану сформованості професійної надійності у діючих вчителів фізичної культури і порівняння отриманих результатів із станом сформованості надійності у майбутніх вчителів.

Оскільки у процесі професійного становлення діючі вчителі фізичної культури проходять низку етапів, починаючи від професійного навчання, відбору, адаптації до професії, професійного зростання тощо, дані отримані у процесі дослідження вчителів ми розглядаємо як модельні, а самі вчителі виступають в якості експертів. Дослідження стану сформованості професійної надійності у діючих вчителів фізичної культури дозволило нам визначити показники та рівні прояву окремих надійністних характеристик. Так, за кожним показником професійної надійності було встановлено шкалу, згідно з якою визначався низький, середній і високій рівень його прояву. Загальний рівень професійної надійності проявлявся на трьох рівнях: пасивнобезкорисному, достатньо-дієвому та активнорезультативному.

Здійснення аналізу стану сформованості професійної надійності майбутніх вчителів фізичної культури і порівняння їх значень із діючими вчителями дозволило, не лише побачити реальний стан, а і намітити основні напрямки щодо вдосконалення професійної надійності, акцентувати увагу на найбільш відстаючих іiі сторонах.

Як показали результати констатувального експерименту найбільші труднощі щодо формування професійної надійності майбутні вчителі мають 3 безпомилковістю, а саме відхиленням уроку від плану конспекту. Згідно із нашим визначенням безпомилковість розраховувалась за сумою часу, витраченого на фізичні вправи, який не співпадав із часом поданим у конспекті уроку. Причинами відхилення було невірне дозування навантаження, недотримання методики викладання, включення до уроку вправ, які не було передбачено у конспекті, невірна уява про можливості учнів тощо.

Окрім цього значне відставання у показниках професійної надійності у майбутніх вчителів виявлено за показником моторна щільність уроку. Незважаючи на прагнення майбутніх вчителів провести гарно урок, відсутність практичного досвіду щодо організації уроку, вибору методів і засобів не давало змови досягти студенту високих показників з рухової активності. Невміння студентів висловити педагогічну вимогу, чітко 
подати потрібну команду, поряд із помилками допущеними під час проведення уроку негативно відбивались на обсязі рухової діяльності учнів.

За показником функціональна самовіддача також встановлено значну розбіжність, проте більшими затратами, більшою роботою серцевосудинної системи характеризуються майбутні вчителі. Невміння пояснити на словах навчальний матеріал студенти замінювали показом i демонстрацією фізичних вправ. Виконання зайвих рухів, разом із надмірним хвилюванням відображалось на підвищеній роботі серцевосудинної системи.

Дещо в меншій степені за іншими показниками також були відмічені відхилення стану сформованості професійної надійності майбутніх вчителів фізичної культури у порівнянні з діючими педагогами. Так, студенти використовують значно менше фізичних вправ для проведення уроку. Гірші показники у майбутніх вчителів фізичної культури також виявлені за загальною щільністю уроку та мовленнєвою самовіддачею.

Виявлені розбіжності у стані сформованості професійної надійності дозволили нам намітити дієві заходи та впровадити їх в освітній процес професійної підготовки майбутніх вчителів фізичної культури.

Для перевірки дієвості реалізації впливів в освітній процес нами було сформовано контрольну i експериментальну групи. Контрольна група навчалась за традиційною системою. Для студентів експериментальної групи використовувались низка методик і відповідних методів, спрямованих на формування професійної надійності. Окрім того, під час професійного навчання в освітньому процесі було реалізовано низку педагогічних умов, зазначених вище.

Особлива увага у ході педагогічного експерименту приділялась покращенню такої характеристики професійної надійності майбутнього вчителя фізичної культури, як безпомилковість. Серед основних помилок, що впливали на збільшення відхилення урокувід плану конспекту, були помилки, пов'язані із дозуванням фізичного навантаження. Майбутній вчитель фізичної культури погано уявляє вплив навантаження на організм учня. Відсутність здатності передбачати реакцію організму на фізичне навантаження проявляється, як під час підготовки плану конспекту, так і безпосередньо під час проведення уроку. Так, майбутні педагоги не завжди вдало підбирали фізичні вправи, погано враховували можливості учнів. Разом із тим мали складності із розрахунком тривалості виконання учнями вправи.
Саме 3 метою формування у майбутніх вчителів фізичної культури відчуття реакції організму учнів на навантаження було запропоновано наступну методику. При підготовці плану конспекту у підготовчій, основній i заключній частинах уроку напроти важливих фізичних вправ вчителем проставлявся прогнозований діапазон ЧСС. Під час виконання даних фізичних вправ майбутній вчитель здійснював підрахунок ЧСС в учнів, щоразу фіксуючи кількість учнів, в яких ЧСС вийшло за межі прогнозованого пульсового коридору. Після уроку майбутній педагог за формулою 1 вираховував власну комплексну оцінку відчуття реакції організму учні на фізичне навантаження.

$$
\text { 1) } D=\frac{\sum_{i=1}^{n}\left(\frac{n_{1}+n_{2}}{n}\right) * 100 \%}{n}
$$

D - комплексна оцінка вчителя відчуття реакції організму на навантаження;

i - кількість замірів ЧСС;

$\mathrm{n}$ - кількість учнів на уроці;

$\mathrm{n}_{1}$ - кількість учнів, яких було перевищено рівень ЧСС;

$\mathrm{n}_{2}$ - кількість учнів, в яких рівень ЧСС був менший діапазону.

Збільшення чисельності учнів, у яких показники роботи серцевої системи виходили за межі, вказувало про недостатню сформованість у педагога уявлення про вплив навантаження обраних ним фізичних вправ.

Серед важливих шляхів покращення вербальної самовіддачі майбутнього вчителя фізичної культури, є збільшення використання слів, прислів'їв, що підбадьорюють активність учнів. Також важливим $є$ знання і використання чітких команд. Саме 3 цією метою під час професійної підготовки кожен майбутній вчитель повинен був сформувати свій власний словник, у якому були зібрані різні слова та прислів’я, що мали мотиваційний характер, сприяли підвищенню бажання в учнів займатись вправами, допомагали учням розвивати вольові якості.

Зважаючи на те, що низка надійністних характеристик в значній мірі залежить від якостей фахівця, під час професійної підготовки окрема увага приділялась розвитку важливих якостей майбутнього вчителя фізичної культури. Також значна увага приділялась формуванню у майбутніх вчителів мотиваційних чинників. Зокрема, зусилля спрямовувались на покращення внутрішньої мотивації, збільшення у майбутніх педагогів відповідальності за власні рішення, розширення свободи вибору тощо.

Дієвість запропонованих заходів, спрямованих 
на формування професійної надійності майбутнього вчителя фізичної культури, було підтверджено результатами педагогічного експерименту, в якому значення показників професійної надійності суттєво покращились в осіб експериментальної групи. Значного приросту в експериментальній групі було досягнуто за показником відхилення від конспекту уроку, що характеризує безпомилковість професійної надійності. Також значимі зрушення було встановлено за показником моторна щільність уроку, що характеризує ефективність професійної діяльності майбутнього вчителя фізичної культури.

Висновки. Існуюча система професійної підготовки майбутніх вчителів фізичної культури не забезпечує в повній мірі формування у них професійної надійності. Здійснення порівняльного аналізу між сформованістю професійної надійності майбутніх і діючих вчителів дозволило виявити значні розбіжності за усіма показниками. Використання під час навчання цілеспрямованого впливу, внесення відповідних змін в освітній процес дозоляє суттєво покращити стан сформованості професійної надійності майбутніх вчителів фізичної культури, що було підтверджено у ході педагогічного експерименту.

Перспективи подальших розвідок у даному напрямку. Здійснення дослідження професійної надійності майбутнього вчителя фізичної культури загалом було побудовано на аналізі якості проведення уроку з фізичної культури і мало актуальний характер. Водночас не менш важливим стає вивчення інших надійністних характеристик, зокрема рівня працездатності вчителя, кількості невиходів на роботу з різних причин, в тому числі і за станом здоров'я, порушення вчителями дисципліни, невиконання в повному обсязі функціональних обов'язків тощо. Ці показники мають потенційний характер професійної надійності і потребують здійснення подальших наукових досліджень.

\section{ЛІТЕРАТУРА}

1. Осадчук О. Л. Модель профессиональной надежности педагога // Высшее образование сегодня. - 2007. - № 5. - С. 64-66.

2. Романов Д. А. Профессиональная надёжность педагога / Инновационные технологии в образовании / Наука. Техника. Технологии. - 2014. - № 2 - С.83-85.

3. Солтик О. Визначення й обгрунтування компонентів, критеріїв та показників професійної надійності вчителя фізичної культури / О.О. Солтик // Обріï. - № 2(45), 2017. C. 74-80.
4. Солтик О.О. Обгрунтування педагогічної системи формування професійної надійності майбутніх вчителів фізичної культури у процесі фахової підготовки / О.О. Солтик // Збірник наукових праць Національної академії Державної прикордонної служби України. Серія: Педагогічні науки. - Хмельницький, 2017. - № 4 (11). C. 404-414.

5. Catharine Parkes and Sarah Maughan. Methods for Ensuring Reliability of Teacher Assessments. Tuesday 2 June 2009, at The Royal Institute of British Architects.

6. Sandra Johnson. On the reliability of high-stakes teacher assessment. Journal Research Papers in Education. Volume 28, 2013 - Issue 1: The Reliability of Public Examinations.

\section{REFERENCES}

1. Osadchuk O. L. (2007). Model professionalnoy nadezhnosti pedagoga [Model of professional reliability of a teacher]. Vyssheye obrazovaniye segodnya, no. 5, pp.64-66. [in Russian].

2. Romanov, D. A. (2014). Professionalnaya nadezhnost pedagoga [Teacher's professional reliability]. Nauka. Tekhnika. Tekhnologii, no. 2, pp.83-85. [in Russian].

3. Soltyk, O. (2017). Vyznachennia y obgruntuvannia komponentiv, kryteriiv ta pokaznykiv profesiinoi nadiinosti vchytelia fizychnoi kultury [Definition and Substantiation of Components, Criteria, and Indices of Professional Reliability of Teacher of Physical Education]. Obriyi, no. 2(45), pp. 74-80. [in Ukrainian].

4. Soltyk, O. (2018). Obgruntuvannia pedahohichnoi systemy formuvannia profesiinoi nadiinosti maibutnikh vchyteliv fizychnoi kultury u protsesi fakhovoi pidhotovky [Substantiation of Pedagogical System of Formation of Professional Reliability of Future Teachers of Physical Education in the Process of Vocational Training]. Collection of scientific works of the National Academy of the State Border Guard Service of Ukraine. Series: pedagogical sciences (printed edition). No 1(9), pp. 404-414.

5. Catharine Parkes and Sarah Maughan. Methods for Ensuring Reliability of Teacher Assessments. Tuesday 2 June 2009, at The Royal Institute of British Architects. [in English].

6. Sandra Johnson (2013). On the reliability of high-stakes teacher assessment. Journal Research Papers in Education. Volume 28, issue 1: The Reliability of Public Examinations. [in English].

Стаття надійшла до редакції 25.10.2018 